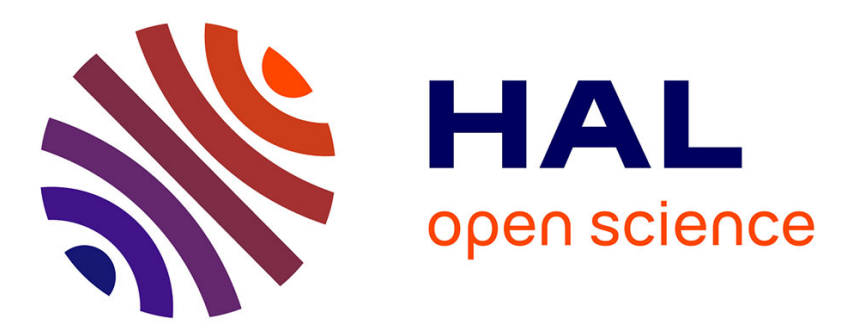

\title{
DISLOCATION RELAXATION IN HIGH PURITY POLYCRYSTALLINE ALUMINUM AT MEGAHERTZ FREQUENCIES
}

M. Zein

\section{- To cite this version:}

M. Zein. DISLOCATION RELAXATION IN HIGH PURITY POLYCRYSTALLINE ALUMINUM AT MEGAHERTZ FREQUENCIES. Journal de Physique Colloques, 1985, 46 (C10), pp.C10-297C10-300. 10.1051/jphyscol:19851066 . jpa-00225450

\section{HAL Id: jpa-00225450 https://hal.science/jpa-00225450}

Submitted on 1 Jan 1985

HAL is a multi-disciplinary open access archive for the deposit and dissemination of scientific research documents, whether they are published or not. The documents may come from teaching and research institutions in France or abroad, or from public or private research centers.
L'archive ouverte pluridisciplinaire HAL, est destinée au dépôt et à la diffusion de documents scientifiques de niveau recherche, publiés ou non, émanant des établissements d'enseignement et de recherche français ou étrangers, des laboratoires publics ou privés. 
JOURNAL DE PHYSIQUE

Colloque C10, supplément au $\mathrm{n}^{\circ} 12$, Tome 46, décembre 1985 page C10-297

\title{
DISLOCATION RELAXATION IN HIGH PURITY POLYCRYSTALLINE ALUMINUM AT MEGAHERTZ FREQUENCIES
}

M. ZEIN

Physics Department, University College of Bahrain, PO Box 1082, Bahrain, Arabian Gulf,

\begin{abstract}
The internal friction of cold-worked polycrystalline aluminum has been measured in the temperature range of $100 \mathrm{~K}$ to $290 \mathrm{~K}$, at frequencies of 10 and 5MHZ, using a conventional ultrasonic pulse technique with a single transducer. Temperature, height and shape of the internal friction peak were studied as a function of the magnitude of stress used in the prior deformation. The results show a large decrease in the peak temperature as the deformation is increased followed by a slight increase as the deformation is continued. An increase in the height of the peak, and decrease in the activation energy has been observed by increasing the deformation.
\end{abstract}

1 - INTRODUCTION

The interest of the present work centered on the study of the Bordoni peak in polycrystailine aluminum of $5 \mathrm{~N}$ purity as a function of plastic deformation, at megahertz frequency. The peak is characterized by its presence only in deformed samples and its shift with frequency which follows a thermally activated relaxation mechanism. The early work on polycrystalline material suggested that, for a given metal at a particular frequency, the Bordoni peak always occurred at the same temperature, apart from variations of a few degrees due to different amounts of prior deformation or impurity content. The measurements of the Bordoni peak in polycrystalline copper as a function of the amount of plastic deformation have shown that the height of the peak has a maximum value for a deformation in the region of $7 \% / 1 \%$ Or has an approximately constant value for deformations greater than about $2 \% / 2 \%$. However Boch /1/ has shown that for aluminum the Bordoni peak height continues to increase up to strain of $30 \%$, while volkl et al. /3/ found similar results for deformations up to $6 \%$. Hassan and Niblett /4/ have shown similar results for $6 \mathrm{~N}$ a luminum for a deformation up to $35 \%$. As these three investigations have been made on aluminum of $4 N 5,5 N$ and $6 N$ purity respectively, Sack $/ 5 /$ and Mayadas $/ 6 /$ have shown that the Bordoni peak in aluminum is very sensitive to the impurity content. All that work has been done at kilohertz frequencies, so I decided to carry out a detailed investigation at megahertz frequencies.

\section{2 - EXPERIMENTAL PROCEDURE}

The specimens used in this investigation were high purity $5 \mathrm{~N}$ aluminum polycrystals, supplied by Metal Research Limited, in the form of cylinders approximately $10 \mathrm{~mm}$ long and $11 \mathrm{~mm}$ in diameter. They are given a successive amount of deformation by compression along the axis of the cylinder in a Monsanto tensometer at room temperature. The ultrasonic attenuation was measured directly after the deformation. The measurement technique was similar to that described by Zein and Niblett $19 \%$. Measurements were made in the temperature range from 100 to $290 \mathrm{~K}$, the temperature being measured with two platinum sensors placed close to the specimen and connected to a Lakeshore digital thermometer and controller. The temperature was held constant while each attenuation measurement was made. 


\section{3 - RESULTS}

The measurements were carried out on two aluminum polycrystalline specimens. The temperature dependence of the ultrasonic attenuation were measured after each series of compressions for a stress ranging up to $80 \mathrm{~N} / \mathrm{mm}^{-2}$. Figure 1 shows the stressstrain curve for one of the specimens.

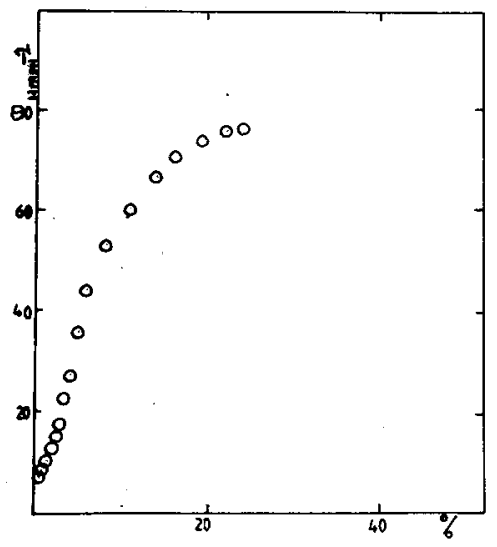

Fig (1) The stress-strain curve for polycrystalline al uminum $5 \mathrm{~N}$.

The measurement showed that the height of the Bordoni peak is increased by increasing the deformation. The peak appeared at temperatures in the range from 186 to 220K. The lower values occurred for larger deformations. The variation of the ultrasonic attenuation with temperature is shown in Figs. 2 and 3.

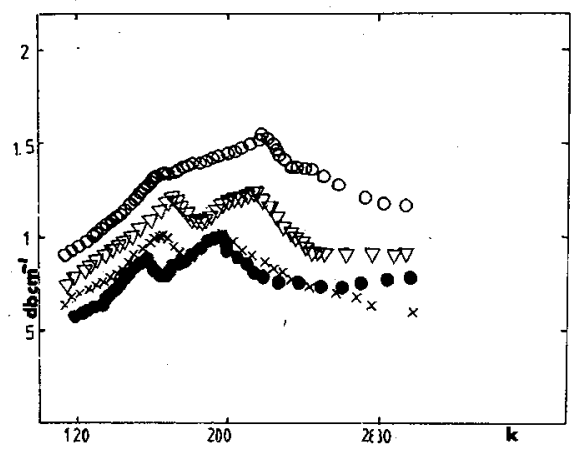

Fig (2) The ultrasonic attenuation of polycrystalline $5 \mathrm{~N}$ a1 uminum as a function of temperature.

(o) $3.5 \mathrm{Nmm}^{-2}$

(D) $5.9 \mathrm{Nmm}^{-2}$

(X) $7 \mathrm{Nmm}^{-2}$

(C) $9.5 \mathrm{Nmm}^{-2}$

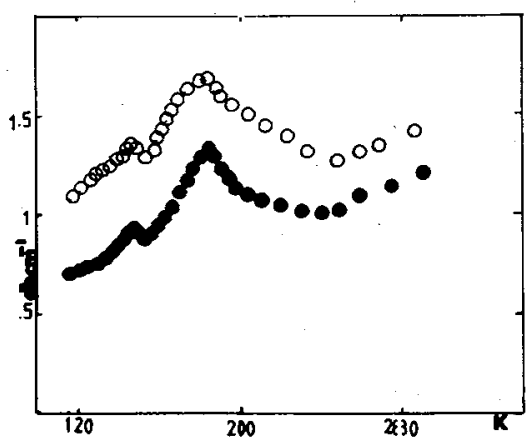

Fig (3) The ultrasonic attenuation of polycrystalline $5 \mathrm{~N}$ a) uminum as a function of temperature.

$35.7 \mathrm{Nmm}^{-2}, 047.6 \mathrm{Nmm}^{-2}$ 
Table 1 lists the peak height and the temperature of the peak, after each stage of deformation.

Table 1

Summary of the Results for $5 \mathrm{~N}$ Polycrystalline Aluminum at $10.2 \mathrm{MHz}$

\begin{tabular}{|c|c|c|c|c|c|c|c|c|c|c|c|c|c|c|c|}
\hline \begin{tabular}{|l|} 
Stress \\
$\mathrm{Nmm}^{-2}$
\end{tabular} & 0 & 1.2 & 2.3 & 3.5 & 5.9 & 7.15 & 9.35 & 14.3 & 17.8 & 23.8 & 29.8 & 35.6 & 47.6 & 59.5 & 77.5 \\
\hline $\begin{array}{l}\text { Main } \\
\text { Peak } \\
\text { Temp Ke }\end{array}$ & - & 220 & 220 & 220 & 215 & 200 & 196 & 190 & 189 & 186 & 186 & 185 & 186 & 188 & 193 \\
\hline $\begin{array}{l}N-W \\
\text { Peak } \\
\text { Temp K } \\
\end{array}$ & - & - & - & - & 170 & 165 & 159 & 155 & 155 & 150 & 150 & 149 & 150 & 151 & 154 \\
\hline $\begin{array}{l}\text { Peak } \\
\text { height } \\
\text { Q } 10^{3}\end{array}$ & & 2.7 & 3.2 & 3.8 & 4 & 4 & 4.4 & 5 & 5 & 6 & 7.2 & 8 & 8.4 & 8.8 & 8.8 \\
\hline
\end{tabular}

A few measurements were made at $5.6 \mathrm{MHz}$, in order to study the variation of the activation energy with deformation.

\section{4 - DISCUSSION}

The variation of the Bordoni peak height with deformation is shown in Fig. 4 which also includes the results of Hassan and Niblett $/ 4 /$.

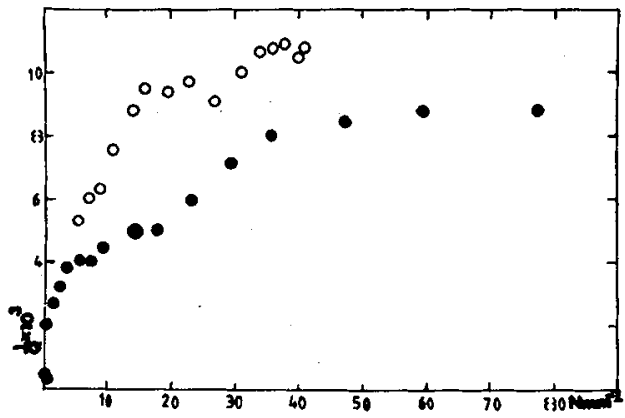

Fig (4) Variation of the Bordoni peak height for al uminum with stress.

(e) - This study

(o) - Hassan and Niblett /4/.

The comparison of the curves shows that the peak height is very sensitive to the impurity content. Our values are comparable as well to those previously obtained for $5 \mathrm{~N}$ aluminum by $\mathrm{Volkl} / 3 /$, and are lower than those found for specimen of higher purity by Hassan and Niblett $/ 4 /$, Deterre et al. $/ 7 /$, and Mayadas $/ 5 /$. The peak grows rapidly up to a stress of $35 \mathrm{Nmm}^{-}$, and then remains approximately constant for higher deformation. This is in agreement with the work done by Hassan and Niblett /4/ and observed in copper by Farman and Niblett $/ 8 /$. I also found that the temperature of the Bordoni peak decreased about thirty five degrees as the deformation was increased. Figure 5 shows the variation of the peak with stress. Its shape is rather similar to that found for aluminum by Hassan and Niblett $/ 4 /$, and that found for copper by $\mathrm{Niblett}$ and Zein $/ 9 /$, and Farman and Niblett /8/, but the magnitude of the shift in the Bordoni peak is greater in the case of aluminum. This large shift is comparable to that found in nickel by Venkatesan and Beshers /10/. 


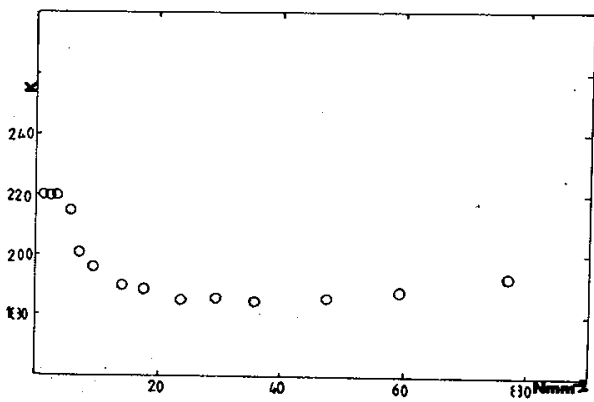

Fig (5) Variation of the Bordoni peak temperature for polycrystalline $5 \mathrm{~N}$ aluminum with prior stress.

This large shift can be attributed to the higher stacking fault energy in aluminum and nickel. In view of the variation in the temperature of the Bordoni peak with prior stress it is important to compare results at different frequencies only on a similarly stressed aluminum when attempting to determine the activation energy of the relaxation process. A comparison of the present results with those at kilohertz frequencies for specimens subjected to similar stresses shows that the activation energy for the Bordoni peak in $5 \mathrm{~N}$ aluminum is approximately $0.186 \mathrm{ev}$ for 1 ight deformation and decreases with increasing stress, reaching $0.165 \mathrm{ev}$ for intermediate stresses and $0.152 \mathrm{ev}$ for heavy deformation. The various theoreticat interpretations of the Bordoni peak have recently been reviewed by Fantozzi et al. /11/, and it is generally agreed that the double kink generation model gives the most satisfactory explanation. The higher peak temperature observed in the lightly deformed specimen is believed to be due to longer dislocation loops occurring at this deformation (Engelke /12/). Higher plastic deformation causes a reduction in the loop length with a consequent reduction of the temperature of the peak. The slight increase in the peak temperature at higher deformation is attributed to a reduction in the internal stress caused by the formation of a cell structure in which a majority of dislocation are located. An interpretation of how the height of the Bordoni peak varies with plastic deformation requires a knowledge of how the dislocation density and the internal stress and loop length distributions vary with prior stress or strain.

\section{REFERENCES}

11/ Bock, P. Thests, Poitiers (1968).

/2/ Niblett, D. H. and Wilks, J., Adv. Phys. 9 (1960) 1.

13/ Volkl, J., Weinlonder, W. and Carsten, J., Phys. Stat. Sol., 10 (1965) 7739.

14/ Hassan, R.A.R. and Niblett, D. H., J. de. Phys. Colloque 44 (1983) C9-659. Fourth European Conference on Internal Friction and UItrasonic Attenuation in Solids (1983).

15/ Sack, H. S., Acta Met. 10 (1962) 455.

/6/ Mayadas, A. F., Thes is, Cornell (1966).

17/ Deterre, Ph., Esnouf, C., Fantozzi, G., Pegin, P., Perez, J., Ritchie, I., Vanoni, F. and Vincent, A., Acta Met. 27 (1979) 1779.

18/ Farman, H. and Niblett, D. H., Internal Friction and Ultrasonic Attenuation in Solids (ed. Smith, C-C) (1980) 7.

/9/ Niblett, D. H. and Zein, M., J. Phys. F. Metal Physics 10 (1980) 773.

$110 /$ Venkatesan, P.S. and Beshers, D. N., J. App 1. Phys. 41 (1970) 42.

/11/ Fantozzi, G., Esnouf, C., Benoit, W. and Ritchie, I. G., Prog. in Mat. Sci., 27 (1982) 311.

/12/ Engelke, H., Phys. Stat. Sol., 36 (1969) 231, 345. 